\title{
PERBEDAAN KADAR ASAM URAT PADA WANITA PERIMENOPAUSE DAN MENOPAUSE
}

\author{
Rini Patroni \\ Politeknik Kesehatan Kementerian Kesehatan Bengkulu, Jurusan Kebidanan \\ Jalan Indragiri Nomor 03 Padang Harapan Bengkulu \\ Email :jmkbengkulu@gmail.com
}

\begin{abstract}
Increased levels of uric acid will occur in women after menopause due to a decrease in estrogen hormones that play an important role in increasing urinary acid excretion through urine. The occurrence of deposition of uric acid continuously in the body so that the kidneys are not able to remove uric acid properly. This study aims to determine differences in uric acid levels in perimenopausal women and menopause at Sukamerindu Health Center Bengkulu City. This study includes comparative study, with cross sectional study design. The sampling technique was purposive sampling as much as 74 respondents, with 37 respondents perimenopause women and 37 respondents of menopause women. Data analysis used univariate and bivariate analysis using independent $t$ test. The mean rate of uric acid levels in perimenopausal women was $5.02 \mathrm{mg} / \mathrm{dL}$ while mean menopausal uric acid level was $7.04 \mathrm{mg} / \mathrm{dL}$ and after statistical test using independent $t$ test, $p$ value 0.0001 , which means $p<0$, 05 then there are differences in uric acid levels in perimenopausal women and menopause at puskesmas sukamerindu city of Bengkulu. The average uric acid levels in menopausal women is higher compared with perimenopausal women so it is expected for menopausal women to maintain health and consume lots of mineral water so that uric acid does not accumulate in the body.
\end{abstract}

Keywords : Uric Acid Level, Perimenopause Women, Women Menopause

\begin{abstract}
Abstrak : Peningkatan kadar asam urat akan terjadi pada wanita setelah menopause akibat adanya penurunan hormon estrogen yang berperan penting dalam peningkatan ekskresi asam urat melalui urin. Terjadinya pengendapan asam urat secara menerus didalam tubuh sehingga ginjal tidak mampu mengeluarkan asam urat dengan baik. Penelitian ini bertujuan untuk mengetahui perbedaan kadar asam urat pada wanita perimenopause dan menopause di Puskesmas Sukamerindu Kota Bengkulu. Penelitian ini termasuk studi perbandingan (study comporatif), dengan desain penelitian cross sectional. Teknik pengambilan sampel yaitu purposive sampling sebanyak 74 responden, dengan 37 responden wanita perimenopause dan 37 responden wanita menopause. Analisis data menggunakan analisis univariat dan bivariat yang menggunakan uji $\mathrm{t}$ independent. Hasil Rerata kadar asam urat pada wanita perimenopause adalah $5,02 \mathrm{mg} / \mathrm{dL}$ sedangkan rerata kadar asam urat wanita menopause adalah $7,04 \mathrm{mg} / \mathrm{dL}$ dan setelah di uji statistik menggunakan uji $\mathrm{t}$ independen didapatkan $p$ value 0,0001 yang artinya $p<0,05$ maka ada perbedaan kadar asam urat pada wanita perimenopause dan menopause di puskesmas sukamerindu kota Bengkulu. Rerata kadar asam urat pada wanita menopause lebih tinggi dibandingkan dengan wanita perimenopause sehingga diharapkan bagi wanita menopause dapat menjaga kesehatan dan banyak mengonsumsi air mineral sehingga asam urat tidak menumpuk didalam tubuh.
\end{abstract}

Kata Kunci : Kadar Asam Urat, Wanita Perimenopause, Wanita Menopause

Peningkatan kadar asam urat darah
akan terjadi pada wanita setelah
menopause akibat adanya penurunan kadar estrogen yang berperan dalam peningkatan ekskresi asam urat melalui urin. Data NHANES menunjukan prevelensi 
hyperurisemia pada kelompok usia lebih dari 65 tahun sebesar 21,6\% pada wanita. Sehingga resiko hyperurisemia pada wanita akan meningkat ketika memasuki usia menopause. Penurunan sekresi estrogen yang terjadi saat menopause juga dapat menyebabkan penumpukan lemak dan menyebabkan obesitas. Obesitas dapat memicu peningkatan kadar asam urat dalam darah sehingga adanya penurunan ekskresi kadar asam urat melalui ginjal (Mulyasari, 2015).

Sebagian besar penyebab asam urat di perkirakan akibat kelainan proses metabolisme dalam tubuh dan $10 \%$ kasus dialami oleh wanita setelah menopause karena gangguan hormon. Hyperurisemia dapat juga menyebabkan kelainan ginjal, penyakit jantung, peradangan tulang, stroke,kencing batu, dan dapat menyebabkan penyakit gout (Diantari, 2012).

Survei yang dilakukan oleh WHOCOPCORD (Community Oriented Program for the Control Of Rheumatic Diseases) di Bandungan Jawa Tengah terhadap 4.683 sampel berusia antara $\geq 45$ tahun, ditemukan bahwa prevalensi gout pada wanita sebesar $11,7 \%$. Berdasarkan data RISKESDAS 2013, prevalensi penyakit sendi meningkat seiring bertambahnya umur. Prevalensi tertinggi pada umur $\leq 75$ tahun sebesar $54 \%$, perempuan memiliki angka lebih tinggi yaitu $(13,4 \%)$ dibanding laki-laki $(10,3 \%)$. Sebagian penyebabnya diperkirakan karena kelainan proses metabolisme dalam tubuh dan $10 \%$ kasus dialami oleh wanita menopause karena gangguan hormon estrogen(Wulandari, 2015).

Tingginya kadar asam urat dalam darah dapat menyebabkan wanita menopause mengalam nyeri, bengkak, merah, dan terasa panas pada bagian sendi yang terserang. Apabila kadar asam urat yang tinggi tersebut tidak dilakukan pengobatan, maka dapat menyebabkan terjadinya gout artritis kronis, sehingga terjadi kelumpuhan karena persendian kaku dan tidak bisa ditekuk lagi. Untuk mengurangi kadar asam urat yang tinggi didalam darah tersebut maka perlu dilakukan pengobatan seperti terapi farmakologi dan non farmakologi (Linasari, 2016).

Faktor penyebab kadar asam urat tinggi yaitu usia, hormon, dan penurunan fungsi ginjal didalam tubuh. Pada wanita menopause adanya penurunan hormon estrogen dan penurunan fungsi ginjal tersebut sangat berpengaruh terhadap kadar asam urat didalam tubuh. Terjadi pengendapan asam urat secara menerus didalam tubuh sehingga ginjal tidak mampu mengeluarkan asam urat dengan baik. Selain itu adanya perilaku hidup tidak sehat seperti mengonsumsi makanan yang mengandung purin tinggi, konsumsi alkohol, obesitas, kurang istirahat serta beraktivitas yang terlalu berat (Linasari, 2016).

\section{BAHAN DAN CARA KERJA}

Metode penelitian yang digunakan study perbandingan (study comporatif). Berdasarkan cara pengumpulan data termasuk jenis penelitian cross sectional. Variabel dalam penelitian ini adalah variabel independent (wanita perimenopause dan wanita menopause) dan variabel dependent (kadar asam urat). Pengolahan data menggunakan analisis univariat dan bivariat. Analisi univariat dilakukan untuk mendeskripsikan karakter setiap variabel penelitian, sedangkan analisis bivariat dilakukan untuk mengetahui perbandingan kadar asam urat pada wanita menopause dan wanita menopause dengan menggunakan uji statistik yaitu uji T Independent. Namun terlebih dahulu melakukan uji normalitas data dengan Shapiro wilk jika populasi $<50$.

\section{HASIL}

Pemeriksaan kadar asam urat telah dilakukan pada 74 responden yang dibagi kedalam 2 kelompok yaitu 37 wanita 
perimenopause dan 37 wanita menopause. Hasil pemeriksaan dapat dilihat pada tabel 1.

Tabel 1. Rerata Kadar Asam Urat pada wanita perimenopause dan menopause

\begin{tabular}{lccc}
\hline & $\mathrm{n}$ & Mean & SD \\
\hline $\begin{array}{l}\text { Kadar asam urat } \\
\text { wanita perimenopause }\end{array}$ & 37 & 5,02 & 0,78 \\
$\begin{array}{l}\text { Kadar asam urat } \\
\text { wanita menopause }\end{array}$ & 37 & 7,04 & 0,92 \\
\hline
\end{tabular}

Tabel 1. menunjukkan bahwa rerata kadar asam urat pada wanita menopause lebih tinggi dibandingkan dengan wanita perimenopause di puskesmas sukamerindu kota Bengkulu. Rerata kadar asam urat pada wanita perimenopause adalah 5,02 $\mathrm{mg} / \mathrm{dL}$ dan Standar Deviasi 0,78 sedangkan rerata kadar asam urat wanita menopause adalah 7,04 mg/dL dan Standar Deviasi 0,92. Untuk melihat apakah ada perbedaan kadar asam urat pada wanita perimenopause dan menopause dilakukan menggunakan uji $\mathrm{T}$ tidak berpasangan disajikan dalam tabel 2.

Tabel 2. diketahui uji $\mathrm{t}$ independen didapatkan $p$ value 0,0001 , berarti $\mathrm{p}<0,05$ maka dapat diambil kesimpulan bahwa ada perbedaan kadar asam urat wanita perimenopause dan menopause di Puskesmas Sukamerindu Kota Bengkulu Tahun 2017.

Tabel 2. Hasil Uji t independen kadar asam urat pada wanita perimenopause dan menopause

\begin{tabular}{|c|c|c|c|c|}
\hline Varian & $\mathrm{n}$ & $\begin{array}{c}\text { Rerata } \\
\pm \mathrm{SD}\end{array}$ & $\begin{array}{c}\text { Perbedaa } \\
\text { n rerata } \\
\text { (IK95\%) }\end{array}$ & $P$ \\
\hline $\begin{array}{l}\text { Kadar asam } \\
\text { urat } \\
\text { perimenopause } \\
\text { Kadar asam } \\
\text { urat } \\
\text { menopause }\end{array}$ & 37 & $\begin{array}{c}5,02 \pm \\
0,78\end{array}$ & $\begin{array}{c}2,02 \\
(1,63- \\
2,42)\end{array}$ & 0,0001 \\
\hline
\end{tabular}

\section{PEMBAHASAN}

Hasil penelitian yang dilakukan di puskesmas sukamerindu kota Bengkulu didapatkan hasil ada perbedaan kadar asam urat pada wanita perimenopause dan menopause. Hasil rerata kadar asam urat pada wanita perimenopause adalah 5,02 $\mathrm{mg} / \mathrm{dL}$, sedangkan pada wanita menopause hasil rerata kadar asam urat adalah 7,04 $\mathrm{mg} / \mathrm{dL}$. kenormalan data dilakukan menggunakan uji Shapiro Wilk. Setelah dilakukan uji t-independent pada sampel didapatkan nilai $\mathrm{p}<0,05$ maka dapat disimpulkan bahwa ada perbedaan kadar asam urat pada wanita perimenopause dan menopause. Hal ini menunjukan hormon esterogen berpengaruh terhadap kadar asam urat, dimana kadar asam urat pada wanita menopause lebih tinggi dibandingkan kadar asam urat pada wanita perimenopause.

Pada penelitian ini dari 37 responden perimenopause di dapatkan kadar asam urat meningkat pada 4 responden, hal ini disebabkan responden tersebut sering mengonsumsi makanan yang mengandung santan dan makanan yang digoreng. Ini disebabkan karena lemak dapat menghambat pengeluaran asam urat melalui urin. Sedangkan pada wanita menopause dari 37 responden di dapatkan hasil kadar asam urat normal pada 6 responden, ternyata responden ini sering mengonsumsi air putih yang cukup yaitu sebanyak 10-12 gelas per hari, juga sering mengonsumsi kopi yang mengandung kafein. Kafein dapat menghambat pembentuan asam urat dalam darah, kafein memiliki struktur kimia sama dengan allopurinol. Allopurinol digunakan sebagai obat asam urat (Hermawati, 2015).

Asam urat mempunyai peran sebagai antioksidan bila dalam keadaan normal, namun bila kadarnya berlebihan dalam darah asam urat akan berperan sebagai prooksidan. Pada kondisi hiperurisemia akan merangsang terjadinya stress oksidatif dan menyebabkan sindrom metabolik (Lelyana, 2011).

Meningkatnya kadar asam urat dalam darah dipengaruhi oleh beberapa faktor seperti genetik, usia, jenis kelamin, obat, riwayat penyakit, asupan makanan, alkohol, asupan cairan dan obesitas. 
Namun pada umumnya, kelebihan kadar asam urat dipengaruhi oleh metabolisme asam urat yang terjadi di luar tubuh melalui asupan makanan yang berlebih dari makanan bersumber protein khususnya purin (Hermawati, 2015).

\section{KESIMPULAN}

Rerata kadar asam urat pada wanita perimenopause dalam keadaan normal, sedangkan rerata kadar asam urat pada wanita menopause meningkat.

\section{DAFTAR RUJUKAN}

Astuti, R. 2013 'Hubungan Tingkat Pengetahuan Tentang Menopause Dengan Tingkat Kecemasan pada Wanita Perimenopause di Dusun Sonopakis Lor rt 2 Bantul Yogyakarta', The indonesian Journal of Public Health, 4.

Fentih, Sugiarto, C. and Novianti 2014 'Perbandingan Kadar Asam Urat Dalam Darah Pada Wanita Menopause Dan Belum Menopause', journal care.

Hariadi. 2016. Hubungan Indeks Massa Tubuh Dengan Kadar Asam Urat Di Dusun Niten Nogotirto Gamping Sleman Yogyakarta.

Hermawati, E. 2015. Hubungan Asupan Kafein Dengan Kadar Asam Urat di Puskesmas Banjarnegara, 1-19.

Kundre, R. M. 2014 'Hubungan Sikap Ibu Premenopause dengan Perubahn yang terjadi Menjelang masa Menopause di kelurahan woloan 1, kecamatan tomohon barat, kota tomohon', Jurnal Care, 2, pp. 12-23.

Linasari, L. M. 2016 'Pengaruh pemberian air beluntas terhadap kadar asam urat pada wanita
Terdapat perbedaan kadar asam urat pada wanita perimenopause dan menopause di puskesmas sukamerindu tahun 2017. Penelitian ini, diharapkan bagi responden khususnya wanita menopause dapat memilih makanan yang tidak menyebabkan kadar asam urat tinggi, karena pada wanita menopause rentan sekali terkena asam urat. Diharapkan bagi responden mengonsumsi air putih 10-12 gelas per hari karena air putih bisa memperlancar asam urat sehingga tidak menumpuk didalam tubuh.

menopause', Jurnal Care, 4(1), pp. 34-41.

Mulyasari, A. 2015 'Faktor Asupan Zat Gizi yang Berhubungan Kadar Asam Urat Darah Wanita Postmenopause', Journal Of Nutrition College, 4(Dm), pp. 387-393.

Saryono (2011) Metodologi Penelitian Kesehatan. Edited by A. Setiawan. Jogjakarta: Nuha Offset.

Sriwaty, I. 2015 'Pengaruh Psikoedukasi Menopause dan Relaksasi untuk Menurunkan Kecemasan Pada Wanita Perimenopause', (274), pp. 1-16.

Sugiarto, C. 2014 'Perbandingan Kadar Asam Urat Dalam Darah Pada Wanita Menopause Dan Belum Menopause', Jurnal e-Biomedik, pp. 24-29.

Ulfiyah, H. 2013 'Hubungan Antara Tingkat Pengetahuan Dengan Prilaku Wanita Menopause Dalam Upaya Pencegahan Penyakit Gout Di Kelurahan Pisangan', pp. 29-30. 